\title{
An effective method for the recapture of escaped farmed salmon
}

\author{
Cedar M. Chittenden ${ }^{1,2, *}$, Audun H. Rikardsen ${ }^{1}$, Ove T. Skilbrei ${ }^{3}$, Jan G. Davidsen ${ }^{1,4}$, \\ Elina Halttunen ${ }^{1}$, Jofrid Skarðhamar ${ }^{3}$, R. Scott McKinley ${ }^{2}$ \\ ${ }^{1}$ Department of Arctic and Marine Biology, University of Tromsø, 9037 Tromsø, Norway \\ ${ }^{2}$ The University of British Columbia, Centre for Aquaculture and Environmental Research, 4160 Marine Drive, \\ West Vancouver, British Columbia V7V 1N6, Canada \\ ${ }^{3}$ Institute of Marine Research, 5817 Bergen, Norway \\ ${ }^{4}$ Museum of Natural History and Archaeology, Norwegian University of Science and Technology (NTNU), 7491 Trondheim, \\ Norway
}

\begin{abstract}
The search for effective strategies to prevent and mitigate accidental releases of aquaculture fishes is on-going. To test a new recapture strategy and evaluate the individual dispersal behaviour of escaped farmed Atlantic salmon Salmo salar L. at the northern limit of its range, 39 adult salmon (mean \pm SD fork length and weight: $85.5 \pm 5.0 \mathrm{~cm}$ and $7.4 \pm 1.4 \mathrm{~kg}$, respectively) were implanted with depth-sensing acoustic tags and released in a north Norwegian fjord during the spring of 2007. The fish were released from 2 aquaculture sites in the Altafjord system and tracked using both mobile and fixed receivers. The coastal marine bag-net fishery, in combination with inriver angling, was tested as a potential recapture strategy. Immediately following the simulated escape event, the fish dove to near-bottom depths, subsequently returning to surface levels within the following days. The fish dispersed rapidly $\left(9.5 \pm 19.2 \mathrm{~km} \mathrm{~d}^{-1}\right)$, traveling outward to coastal waters along the edges of the fjord. The bag-net fishers and anglers recaptured $79 \%$ of the escaped fish within 1 mo post-release, $90 \%$ of which were from bag nets. While most of the fish left the fjord, 7 tagged fish (18\%) entered the Alta River estuary ( 3 of which later migrated up the Alta River), and 1 returned to the Altafjord the following year, presumably to spawn. The results showed that recapture efforts need to be immediate and widespread to mitigate farm-escape events. Coastal bag nets were effective at recapturing escaped farmed salmon, compared to previously tested methods, and would be especially useful in areas where gill-netting is not permitted.
\end{abstract}

KEY WORDS: Acoustic telemetry · Aquaculture - Dispersal behaviour · Migration · Mitigation • Net fishery $\cdot$ Salmo salar

\section{INTRODUCTION}

Every year, large numbers of farmed fish escape into the wild (NDF 2010). The effects of these escaped fish on local ecosystems have been a major concern for the past 20 yr (Gausen \& Moen 1991, Hindar et al. 1991, Lura \& Sægrov 1991, McGinnity et al. 1997, Clifford et al. 1998, Fleming et al. 2000, Skaala et al. 2006, Roberge et al. 2008, Skilbrei et al. 2009). However, efficient prevention and mitigative strategies are lacking (Fiske et al. 2006, Hansen 2006, Skilbrei et al. 2009).
Norway is the top-producing country of farmed Atlantic salmon, with over $850000 \mathrm{t}$ sold in 2009 alone (NDF 2010). From 2004 to 2009, the mean number of reported salmon escapes was over 457000 fish $\mathrm{yr}^{-1}$ (NDF 2010). However, the actual number of escapes is difficult to ascertain and is probably much greater than the number reported (Baarøy et al. 2004, Skilbrei \& Wennevik 2006). Meanwhile, both the freshwater and marine catches of Atlantic salmon in Norway are breaking low level records yearly (Statistics Norway 2010), with escaped farmed salmon making up 20 to 
$75 \%$ of the resident 'wild' population in some areas (Lund et al. 1991, Hansen et al. 1999, Fiske et al. 2001, Youngson et al. 2001, Carr \& Whoriskey 2006, Hindar et al. 2006, Erkinaro et al. 2010). The reduction in the genetic differentiation of wild Atlantic salmon Salmo salar L. due to genetic mixing with farmed escapes in some cases reported to be as high as $70 \%$ - may be driving some native spawning populations to extinction (Hutchings 1991, Mork 1991, McGinnity et al. 2003, Ford \& Myers 2008).

Methodologies for the rapid detection and recapture of escaped farmed fish are urgently needed (Uglem et al. 2010). Past studies on escapee behaviour found that recapture fisheries are a realistic option for reducing the impact of escape events (Uglem et al. 2010). However, fishing efforts need to be initiated immediately following the event and cover a large area, as salmon may either remain near the farm site (Olsen \& Skilbrei 2010) or disperse rapidly following release (Skilbrei et al. 2010). A study in southern Norway found that trawling for escapees was not very efficient, whereas gillnetting had greater success, especially when carried out over a large area for an extended period (Skilbrei \& Jørgensen 2010). As salmon tend to be surfaceoriented, nets set near the surface were most effective (Skilbrei et al. 2009).

To test other recapture methods and gain a more detailed understanding of escapee dispersal behaviour (including dispersal rate, swimming depth, habitat use), tagged adult farmed salmon ( $\mathrm{n}=39$ ) were monitored in 2 north Norwegian fjords. The study was conducted during the peak return run of the wild salmon to the Alta River, which allowed for a comparison of escapee and wild salmon behaviour in the same time and place, as well as an estimate of the effectiveness of coastal marine bag-net fishers and in-river anglers as part of a recapture strategy for escaped farmed salmon.

\section{MATERIALS AND METHODS}

Study site. The Altafjord $\left(70^{\circ} 12^{\prime} \mathrm{N}, 23^{\circ} 6^{\prime} \mathrm{E}\right.$; Fig. 1) is a wide Arctic fjord with a deep sill $(190 \mathrm{~m})$. Thus, the dynamics in the fjord are influenced substantially by the Coriolis effect and tidal exchange with coastal waters (Svendsen 1995, Eilertsen \& Skardhamar 2006, Skarðhamar \& Svendsen 2010). The Alta River enters the Altafjord from the south (Fig. 1), and is one of the most productive salmon rivers in Europe (Ugedal et al. 2008). Accordingly, the Altafjord has been designated a National Salmon Fjord, which is a type of marine protected area that was created to protect wild salmon populations from the negative effects of fish farms. However, aquaculture continues to be present in the Altafjord system.

The 2 aquaculture sites used in this study were located in Langfjord and Kåfjord, 2 side fjords entering the Altafjord from the west (Fig. 1). In Kafjord, the depth ranged from 20 to $40 \mathrm{~m}$ within $600 \mathrm{~m}$ of the farm. Langfjord was deeper, ranging from 40 to $130 \mathrm{~m}$ within $600 \mathrm{~m}$ of the farm. With the release site north of the Arctic Circle, the main study period took place during days which had $24 \mathrm{~h}$ of sunlight. Measurements of temperature and salinity were taken in the Altafjord by data recorders moored 1.5 and $5 \mathrm{~m}$ below the surface (Davidsen et al. 2009). The mean fjord water temperature and salinity \pm SD from 6 June to 6 July 2007 were $10.9 \pm 2.1^{\circ} \mathrm{C}$ and $21.4 \pm 8.1$ at $1.5 \mathrm{~m}$, and $7.2 \pm 0.9^{\circ} \mathrm{C}$ and $31.3 \pm 2.7$ at $5 \mathrm{~m}$.

Sea-level data for the Altafjord (position $\left.70^{\circ} 10^{\prime} \mathrm{N} ; 23^{\circ} 06^{\prime} \mathrm{E}\right)$ were downloaded from the Norwegian Hydrographic Service website (www. vannstand.no/). The sea-level data were used to correlate the outmigration timing of tagged fish with tidal phase.
Fig. 1. Study area, divided by transects into the following zones: outer Altafjord (AO), middle Altafjord (AM), inner Altafjord (AI), Alta estuary (AE), Alta River (AR), Kåfjord (KF), and Langfjord (LF). Tanafjord and Hardangerfjord are indicated on the inset map of Norway. Farm release locations are marked by a fish, and hydrophone receiver (VR2) locations are shown as black circles ( $\mathrm{n}=74 \mathrm{VR} 2 \mathrm{~s}$ ). Bag nets were located at a maximum density along the coastlines of $\mathrm{AE}, \mathrm{AI}, \mathrm{AM}$ and $\mathrm{AO}$ 
Surgery and release. A total of 39 adult Atlantic salmon (age 2 yr) were surgically implanted with acoustic depth tags (Vemco, model V13P-1L, $13 \times$ $36 \mathrm{~mm}$, mass in water/air of 6/11 g) using methods described in Halttunen et al. (2009). An external Carlin tag was also attached, containing contact and reward information. Local fishermen were informed about the study through mail correspondence and the media, and were encouraged by reward to report all recaptures.

The freshwater rearing site for the farmed fish was located further south along the Norwegian coast. Thus, the fish were not imprinted to the farm area as smolts. The study fish were fully grown and potentially maturing adult salmon that would have been slaughtered within a week or two of the tagging dates. The fat content of each fish was estimated using a Distell Fish Fatmeter (www.distell.com/). Following surgery, the fish were returned to a recovery net pen at the farm site.

The mean period of time spent by the fish in anaesthetic was 3:55 \pm 0:53 min:s. Surgeries (including insertion of the internal acoustic tag, the external Carlin tag and measurements of weight and length) took 5:20 \pm 1:42 min:s. The fish recovered in 4:44 $\pm 5: 13 \mathrm{~min}: \mathrm{s}$ and spent 3:07:17 \pm 0:52:02 h:min:s in the recovery pen prior to release. The releases were carried out at high and low tide, and spaced out (4 to 6 fish per release) to reduce the chance of tag-code collisions. At the Langfjord farm site, the tagged fish were released at high and low tide on 6 and 11 June 2007. At the Kåfjord site, the tagged fish were released at high and low tide on 8 and 12 June 2007 (Table 1).

Detection and recapture. Acoustic receivers (VR2, Vemco) were located at the end of each release fjord, at the fish farm site, and in the Alta River (Fig. 1). There were also transects dividing the Altafjord area into 6 sections - Langfjord (LF), Kåfjord (KF), Outer Altafjord (AO), Inner Altafjord (AI), Middle Altafjord

Table 1. Salmo salar. Physical characteristics and behaviour (mean $\pm \mathrm{SD}$ ) of escaped farmed fish by release group. HT: high tide; LT: low tide. N tagged: number of fish tagged, includes release group sizes in brackets; FL: fork length; $\mathrm{N}$ with PR gap: no. of tagged fish with a gap in detection immediately postrelease; max. depth: maximum depth recorded for each fish during the first hour post-release; $\mathrm{T}$ out of fjord: time taken by the group to leave the release fjord; progression rate: rate at which the released farmed fish left their release fjord

\begin{tabular}{|lcccc|}
\hline Release group & Kåfjord HT & Kåfjord LT & Langfjord HT & Langfjord LT \\
\hline N tagged & $10(5,5)$ & $10(4,6)$ & $10(5,5)$ & $9(4,5)$ \\
FL (cm) & $86.9 \pm 7.1$ & $84.4 \pm 3.2$ & $86.5 \pm 4.9$ & $84.3 \pm 4.3$ \\
Weight (kg) & $8.1 \pm 1.6$ & $7.0 \pm 1.0$ & $7.6 \pm 1.6$ & $7.0 \pm 1.2$ \\
\% fat & $15.3 \pm 3.8$ & $13.8 \pm 0.9$ & $12.5 \pm 1.9$ & $12.8 \pm 1.6$ \\
N with PR gap & 0 & 1 & 6 & 3 \\
Max. depth (m) & $21.2 \pm 9.1$ & $21.3 \pm 6.1$ & $18.3 \pm 10.5$ & $29.3 \pm 19.5$ \\
T out of fjord (h) & $44.1 \pm 35.0$ & $59.1 \pm 83.3$ & $146.9 \pm 197.6$ & $132.1 \pm 145.2$ \\
Progression rate & $2.6 \pm 3.1$ & $2.6 \pm 2.7$ & $23.0 \pm 32.4$ & $9.7 \pm 14.3$ \\
$\quad\left(\mathrm{~km} \mathrm{~d}^{-1}\right.$ ) & & & & \\
\hline
\end{tabular}

(AM), and Altafjord Estuary (AE) - for a total of 74 receivers (Fig. 1).

The VR2s in the transects were placed $400 \mathrm{~m}$ apart and moored $5 \mathrm{~m}$ below the surface, except for in $\mathrm{AE}$ where they were $3 \mathrm{~m}$ below the surface due to shallower water. Range testing trials demonstrated that the acoustic tags used in this study were recorded by the receivers at a distance of 600 to $800 \mathrm{~m}$ (minimum-maximum range). Thus, at the receiver lines, the detection probability was likely to be $100 \%$. The distance between the receiver lines was $10 \mathrm{~km}$ from the inner to the middle line, and $15 \mathrm{~km}$ from the middle to the outer line.

Following each release, manual tracking was carried out near the release site using a mobile VR100 (Vemco) for $2 \mathrm{~h}$. The grid searches began $300 \mathrm{~m}$ from shore, near the release site, and then extended in concentric circles with each listening point $800 \mathrm{~m}$ apart. At least 3 min were spent at each point, as the tags were designed to transmit their codes every 40 to $120 \mathrm{~s}$. Additional grid searches were carried out to determine whether all the fish had left the farm vicinity in Langfjord on 9, 13, 19 and 29 June 2007, and in Kåfjord on 10, 14 and 19 June 2007.

Bag nets have been used as a traditional fish capture method in the Altafjord. The nets form live traps, guiding the fish into a net enclosure where they can be collected. Coastal bag-net fishers in the middle and outer parts of the Altafjord, as well as anglers in the Alta River (Fig. 1) were present for the duration of the study, testing the effectiveness of these methods at recapturing farmed salmon in both marine and riverine environments. There were 246 registered bag-net fishing cations in the Altafjord management area during 07, with an average of $30 \pm 16$ (range: 5 to 53) nets ing each week, from Week 21 to 31. A reported $32873 \mathrm{~kg}$ of salmon were caught by Altafjord bag-net fishers in the ocean during 2007. There were also $138 \pm$ 39 rod fishers in the Alta River per week from Week 22 to 35.

Analyses. The data were first filtered for false detections (detections occurring only once on a line in $1 \mathrm{~h}$, with one or more tags detected by the same receiver at the same time, without supporting detections along the migratory path). Physiological differences between release groups were compared using Student's $t$-test. The locations of the tagged fish were noted at the end of each day $(24: 00 \mathrm{~h})$. In a couple of cases, the exact location of a tagged fish was not known for certain - for example, when a fish was last detected at the outer transect and could have entered the AM or AO areas following 
detection. In these cases, if the fish was neither recaptured nor detected again, it was assumed that they were in the $\mathrm{AO}$ area.

The time taken for a fish to leave its release fjord was calculated from the time of release to the time of its last detection at the fjord mouth receivers. Chi-squared tests were used to compare dispersal rates and to detect tidal phase effects on group fjord-exit time. The tidal cycle was divided into four $3 \mathrm{~h}$ phases: high-water slack ( $\pm 1 \mathrm{~h}$ from the highest tide), ebbing (from high to low tide), low-water slack ( $\pm 1 \mathrm{~h}$ from the lowest tide), and flooding tide (from low to high tide).

The mean group swimming depths were calculated by days post-release from the daily means for each fish, and compared using a general linear model. The detections at each receiver were summarized as the number of fish days, where each tag was counted once on each day that it was detected. The mean swimming depths at each receiver were calculated from the mean fish-day depths. The receiver data was grouped into nearshore (defined as the closest 3 receivers to each shoreline) and offshore groups (receivers farther than $1 \mathrm{~km}$ from shore) and compared with Student's $t$-test. Significance in all cases was established at $\mathrm{p}<0.05$.

\section{RESULTS}

The 20 fish tagged in Kåfjord weighed $7.5 \pm 1.4 \mathrm{~kg}$ (mean $\pm \mathrm{SD}$ ) and had a mean FL of $85.7 \pm 5.5 \mathrm{~cm}$ (Table 1). Their mean fat content was estimated to be $14.9 \pm 3.4 \%$. At the farm in Langfjord, the 19 tagged fish weighed $7.3 \pm 1.4 \mathrm{~kg}$, had a FL of $85.4 \pm 4.6 \mathrm{~cm}$ and $12.6 \pm 1.7 \%$ body fat (Table 1 ). No differences were found between release groups in terms of weight, length, or fat content (Student's $t$-test, $\mathrm{p}>0.05$; $\mathrm{n}$ values in Table 1).

\section{Vertical behaviour}

Within the first hour post-release, the tagged fish dove to near-bottom depths in both fjords (20 to $40 \mathrm{~m}$ in Kåfjord, 40 to $130 \mathrm{~m}$ in Langfjord; Table 1). In Kåfjord, the fish dove to a mean $( \pm \mathrm{SD})$ maximum depth of 21.3 $\pm 7.6 \mathrm{~m}$ during the first hour $(\mathrm{n}=19$; Table 1$)$, and had a mean swimming depth of $6.6 \pm 4.2 \mathrm{~m}$ during the first day post-release ( $\mathrm{n}=20$; Fig. 2). In Langfjord, the mean maximum depth of the fish during the first hour postrelease was $26.1 \pm 15.6 \mathrm{~m}(\mathrm{n}=10$; Table 1$)$, and the greatest recorded depth was $111.6 \mathrm{~m}$. The mean swimming depth during the first day post-release was $9.1 \pm$ $9.7 \mathrm{~m}(\mathrm{n}=19$; Fig. 2). Following this initial dive period, the fish ascended to reside primarily near the surface, after which there was no difference in mean daily

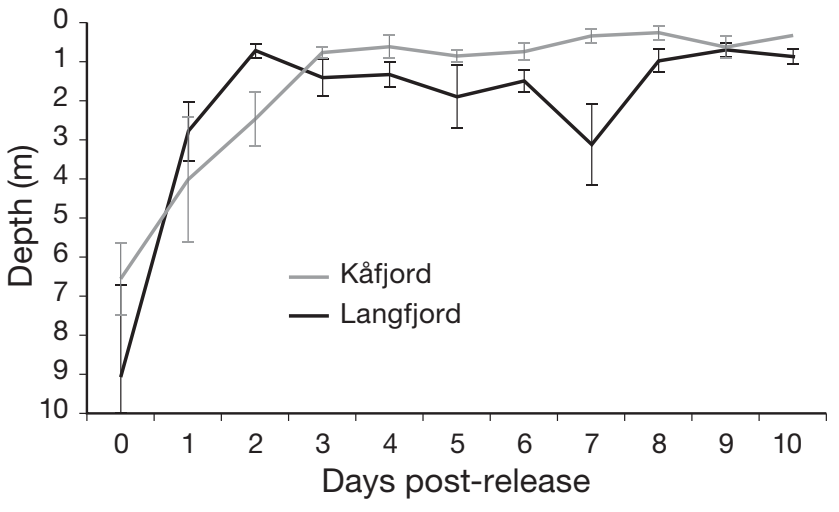

Fig. 2. Salmo salar. Mean $( \pm \mathrm{SE})$ swimming depth of the tagged farmed salmon by day post-release

swimming depth between fjord release groups ( $p>$ 0.05; Fig. 2).

At the outer Altafjord transect, the mean of the fishday swimming depths for each receiver were greater at the middle receivers than on the receivers that were closer to shore $(p<0.05 ;$ Fig. 3$)$. At the middle and inner transects, the mean swimming depths were similar from west to east ( $p>0.05$; Fig. 3 ).

\section{Dispersal behaviour}

A post-release gap in detection for up to $10 \mathrm{~h}$ was observed for many fish, but primarily in the deeper Langfjord (Table 1). In Langfjord, 9 fish were not detected until a mean $( \pm \mathrm{SD})$ of $15.0 \pm 21.2 \mathrm{~h}$ post-release. In Kåfjord, 2 of the tagged fish immediately went undetected in the farm area for 1 and $3 \mathrm{~h}$, respectively.

In both Langfjord and Kåfjord, more than twice as many fish (each $\mathrm{n}=13$ ) were recorded at a high-water slack or ebbing tide, than at a low-water slack or flooding tide (4 in Langfjord and 5 in Kåfjord) during the first 3 wk post-release (chi-square test, Langfjord: $\mathrm{n}=$ 17, $\mathrm{p}=0.03$; Kåfjord: $\mathrm{n}=18, \mathrm{p}=0.06$; Table 2).

The fish that were released in Kåfjord took $2.4 \pm$ $2.5 \mathrm{~d}$ (mean $\pm \mathrm{SD}, \mathrm{n}=20$ ) to leave the release fjord,

Table 2. Salmo salar. Number and percentage (in brackets) of out-migrating farmed fish in relation to tidal phase. Tidal cycle was divided into four $3 \mathrm{~h}$ phases: high-water slack $( \pm 1.5 \mathrm{~h}$ from the highest tide), ebbing (from high to low tide), low-water slack ( $\pm 1.5 \mathrm{~h}$ from the lowest tide), and flooding tide (from low to high tide)

\begin{tabular}{|lcc|}
\hline Tide & Langfjord & Kåfjord \\
\hline High-water slack & $5(29)$ & $6(33)$ \\
Ebbing & $8(47)$ & $7(39)$ \\
Low-water slack & $1(6)$ & $2(11)$ \\
Flooding & $3(18)$ & $3(17)$ \\
\hline
\end{tabular}



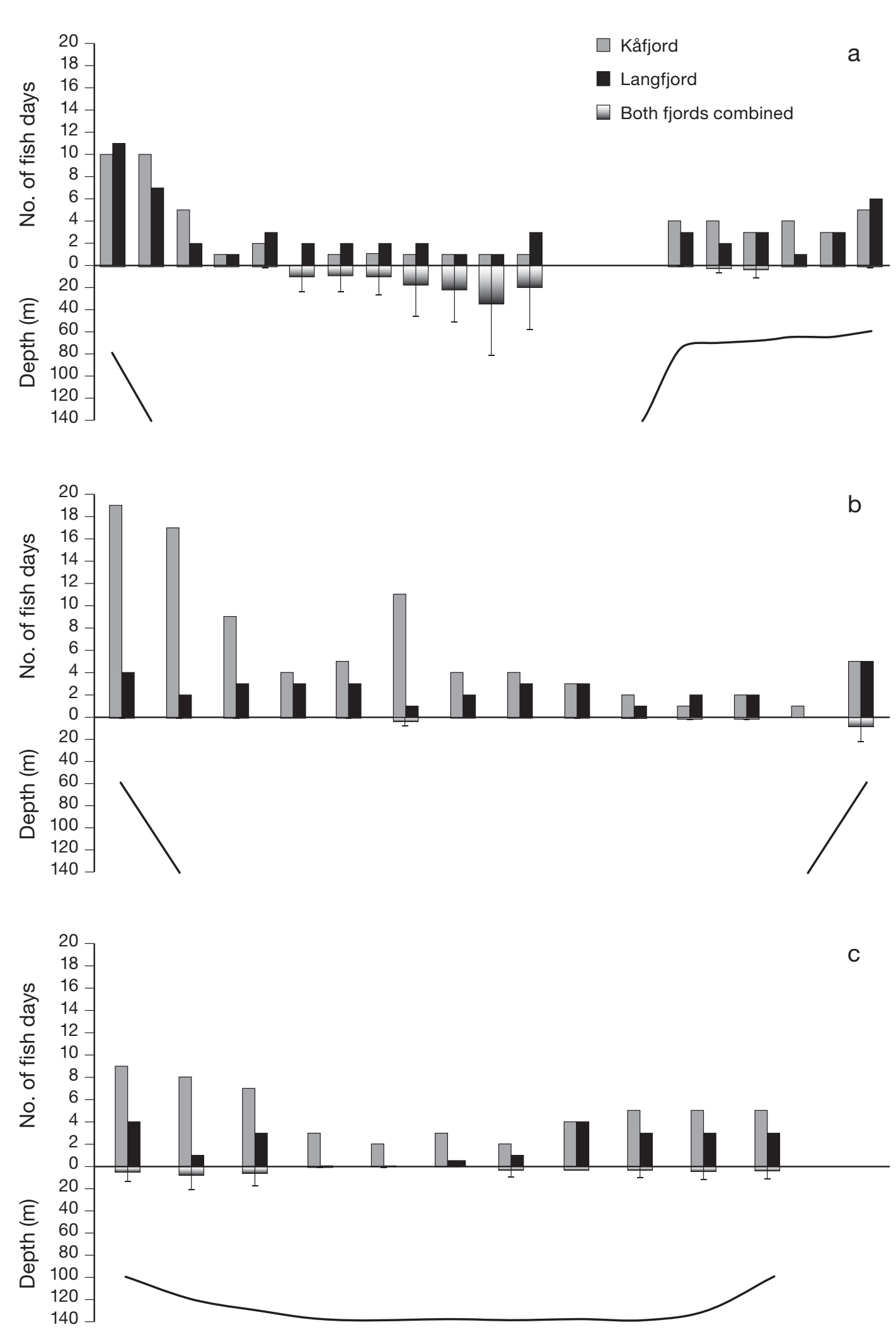

Fig. 3. Salmo salar. Horizontal distribution of detections and mean $( \pm$ SD) swimming depths of tagged salmon at the (a) outer, (b) middle, and (c) inner Altafjord transect receivers, from west to east, for Kåfjord and Langfjord (see Fig. 1). Detections were summarized in the number of fish days, where each tag was counted once on each day that it was detected. Solid line: bottom depth, descending to $400-450 \mathrm{~m}$ at the outer and middle transects 


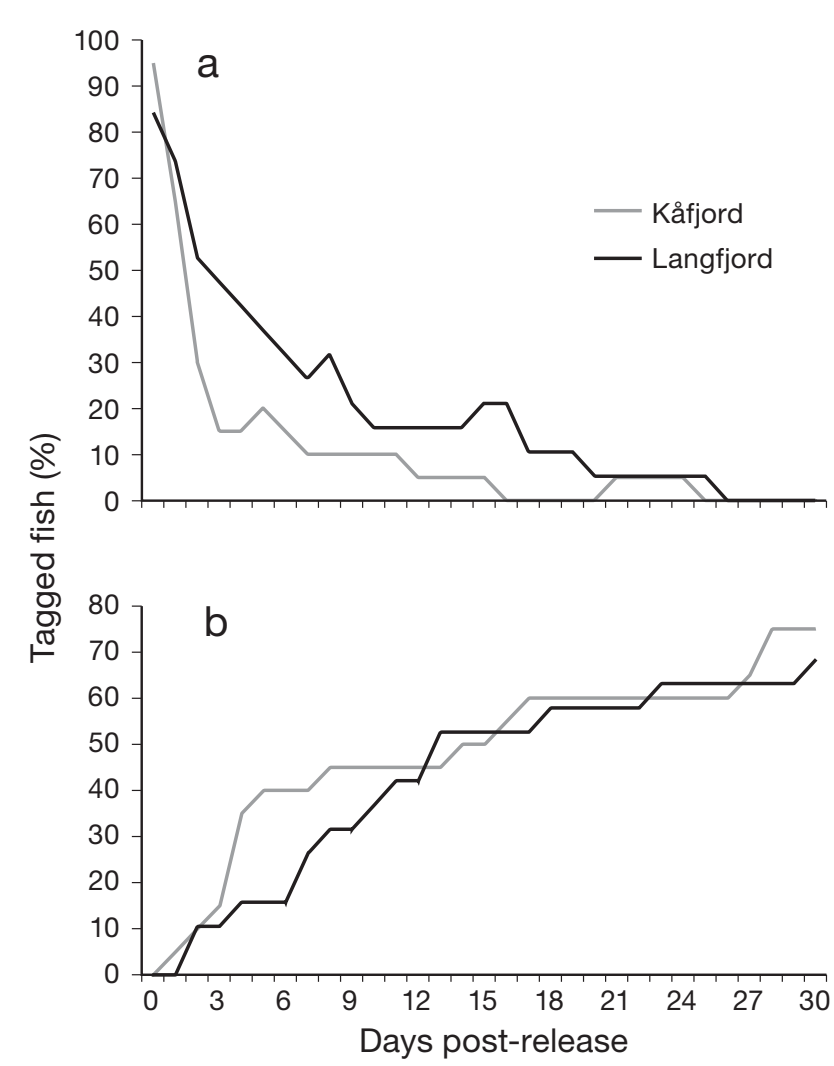

Fig. 4. Salmo salar. Percentage of tagged fish (a) remaining in the release farm fjords and (b) recaptured up to $30 \mathrm{~d}$ postrelease, for Kåfjord and Langfjord

whereas those in the Langfjord took longer $(6.0 \pm 7.1 \mathrm{~d}$, $\mathrm{p}<0.05, \mathrm{n}=18$; Fig. 4). There was no difference between the within-fjord release groups in terms of time taken to leave the release fjord in either Kåfjord ( $\mathrm{p}=$ $0.6)$ or in Langfjord ( $p=0.9$; Table 1).

Three of the Kåfjord releases were later detected in Langfjord (2, 5 and $11 \mathrm{~d}$ post-release), and 1 fish returned to Kåfjord during Day 5 post-release (Fig. 5). After 7 d post-release, no fish were detected in Kåfjord, and the receivers were removed $32 \mathrm{~d}$ post-release. None of the Langfjord releases were detected entering Kåfjord, but 2 returned to Langfjord 8 and $15 \mathrm{~d}$ postrelease (Fig. 5). After $27 \mathrm{~d}$ post-release, no fish were detected in Langfjord, and the receivers were removed $32 \mathrm{~d}$ post-release (Fig. 5).

In general, the tagged fish travelled in all directions following release. The Kåfjord releases first arrived at the outer Altafjord transect $4.4 \pm 4.0 \mathrm{~d}$ post-release

Fig. 5. Salmo salar. Number of tagged salmon detected (grey bars) and recaptured (black bars) in the study zones (see Fig. 1) from release to $400 \mathrm{~d}$ post-release, for Kåfjord and Langfjord. Six representative time periods were selected to best display the groups' movement patterns. $\star$ : a fish that left the Altafjord for 1 yr and was recaptured upon its return, $387 \mathrm{~d}$ post-release
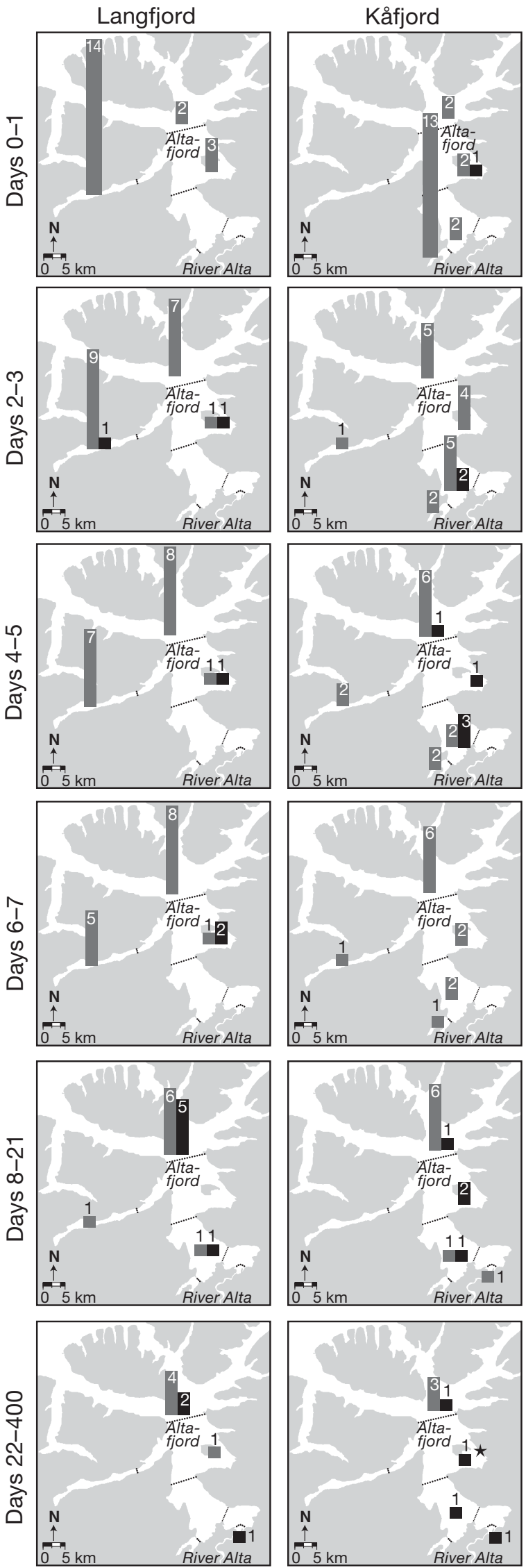
(mean $\pm \mathrm{SD}, \mathrm{n}=10)$, whereas the Langfjord releases took $7.7 \pm 8.5 d(n=13 ;$ Fig. 5). The progression rate of the fish from their release site to the release-fjord transects varied from 0.2 to $90.0 \mathrm{~km} \mathrm{~d}^{-1}$ (mean: $9.5 \pm 19.2 \mathrm{~km} \mathrm{~d}^{-1}$ ).

At the outer receiver line, a greater number of fishdays were recorded by the nearshore than the offshore receivers ( $p<0.05$; Fig. 3 ). At the middle and inner receiver lines, the Kåfjord fish were more likely to be detected by nearshore receivers than offshore receivers $(p<0.05)$, whereas the detections of the Langfjord fish were evenly distributed.

Results from another acoustic telemetry study in the fjord at the same time found similar behaviour exhibited by escaped farmed fish that were already present in the Altafjord (J. G. Davidsen et al. unpubl. data). Eight untagged farmed fish were captured by bag-net fishers, whereupon they were tagged and released in the Altafjord during early July 2007. Six out of 8 of these fish left the fjord during late July, one of which had been detected at the river mouth previously. The remaining 2 fish were last detected at the mouth of the Alta River during August/September (J. G. Davidsen et al. unpubl. data).

\section{Recaptures}

A total of $79 \%$ of the tagged fish were recaptured, both by the coastal net fishery (69\%) and anglers (10\%). Nearly all of the fish were recaptured by coastal fishers within 1 mo of their release (Fig. 4). Of the total recaptures, 32\% were made in outer Altafjord, 29\% in middle Altafjord, and $26 \%$ in inner Altafjord (Table 3). Anglers accounted for the recaptures in Langfjord

Table 3. Salmo salar. Final recapture and detection locations (in days postrelease, dpr) and mean dpr $( \pm \mathrm{SD})$ at the final known locations, of the tagged farmed salmon (N). The proportion of each fjord-release group (Kåfjord and Langfjord, \% FG) recaptured/last detected in each location is also included. AI: inner Altafjord, AM: middle Altafjord, AO: outer Altafjord, AR: Alta River, TR: Tana River, LF: Langfjord

\begin{tabular}{|llcccc|}
\hline Location & Recapture (dpr) & Last detected (dpr) & Mean dpr & N & $\%$ FG \\
\hline Kåfjord & & & & & \\
AM & $1,4,8,14,387$ & - & $6.8 \pm 5.6^{\text {a }}$ & 5 & 25 \\
AI & $2,3,4,4,4,17,28$ & - & $8.9 \pm 9.9$ & 7 & 35 \\
AO & $5,16,28$ & $13,17,35$ & $19.0 \pm 10.8$ & 6 & 30 \\
AR & 27 & - & $27.0 \pm 0.0$ & 1 & 5 \\
TR & 63 & - & $63.0 \pm 0.0$ & 1 & 5 \\
Langfjord & - & & & \\
LF & 2 & - & $2.0 \pm 0.0$ & 1 & 5 \\
AM & $2,4,7,7$ & 31 & $10.2 \pm 11.8$ & 5 & 26 \\
AI & 18 & - & $18.0 \pm 0.0$ & 1 & 5 \\
AO & $8,10,11,13,13,23,30$ & $3,17,20,153$ & $14.8 \pm 7.9^{\mathrm{a}}$ & 11 & 58 \\
AR & 40 & - & $40.0 \pm 0.0$ & 1 & 5 \\
aFish caught 387 and 153 dpr were excluded as outliers & & \\
\hline
\end{tabular}

(3\%), the Alta River (6\%), and the Tana River (3\%). Whereas most of the fish released from Kåjord were recaptured in the inner and middle Altafjord areas $(71 \%)$, those from Langfjord were caught primarily in the outer Altafjord area (50\%; Table 3$)$.

One fish was captured in the Tana River (Figs. 1 \& 5), $\sim 450 \mathrm{~km}$ (shortest possible route) from its release site, 63 d post-release (14 August 2007). This fish was a maturing female, weighing $6.6 \mathrm{~kg}(7.4 \mathrm{~kg}$ at release) and measuring $85 \mathrm{~cm}$ (83 $\mathrm{cm}$ at release). It was released from Kåfjord on 12 June 2007, and was last detected the next day at the outer Altafjord transect. Over 1 yr after its release, a fish from the same release group was recorded at the outer Altafjord transect (3 July 2008; 387 d post-release) before being caught later that day in the middle Altafjord area $(83 \mathrm{~cm}$ at release, $96 \mathrm{~cm}$ at recapture). The fish had not been detected for $385 \mathrm{~d}$ since its last detection at the outer Altafjord transect on 14 June 2007.

\section{DISCUSSION}

Coastal bag-net fishers and anglers were highly successful at recapturing escaped farmed salmon during the month following their release. The fish dove and dispersed rapidly following their release, travelling primarily along the shorelines, near the surface, and in the direction of the open ocean, with a small proportion entering freshwater, and 1 fish returning to the release fjord 1 yr later. The extremely high and efficient recapture rate in the present study (nearly $80 \%$ ) was exceptional. Previous experimental release studies reported rates of $1 \%$ using trawlers, and 18.5 to $67 \%$ using gill nets (Skilbrei \& Jørgensen 2010, Skilbrei et al. 2010). Thus, bag-net fishing combined with in-river angling has great potential as a new strategy for recapturing escaped farmed fish. Further, as primarily non-lethal fishing techniques, bag-net fishing and angling can be used where lethal methods (e.g. gill-netting) are not permitted, for example during times when protected wild stocks are migrating.

The immediate inclination to dive and flee the farm area could be an instinctive response to a sudden change in environment (from high-density sea cages ca. 20 to $25 \mathrm{~m}$ deep). Similar behaviour was observed at escape events in more southern regions (Whoriskey et al. 2006, Skilbrei et al. 2009), which means that recapture efforts near the farm site during the first couple of days 
following an escape event may need to cover all depths. However, Walker et al. (2000) found similar results in non-farmed fish, which suggests that the observation could be merely an effect of handling and tagging. Although, results from studies in southern Norway offer evidence to the contrary, as the releases were 5 to $7 \mathrm{~d}$ after tagging (Skilbrei et al. 2009).

The tendency of the escaped farmed salmon to travel close to the surface along the shoreline of the Altafjord was similar to patterns found in returning wild salmon and outmigrating kelts (Halttunen et al. 2009, J. G. Davidsen et al. unpubl.), and was likely a major factor in the success of bag nets as a recapture method.

The geographical characteristics of the farm fjord should be considered in recapture strategy planning. Salmonid feeding patterns differ between long, narrow fjords (typical of southern Norway), and shorter, wider fjords that are more open to coastal currents (typical of northern Norway; Rikardsen et al. 2004). Vertical habitat use and dispersal patterns may also vary depending on fjord bathymetry and complexity. The fish in Langfjord, a deeper and longer fjord than Kåfjord, had a greater mean maximum dive depth and more variance in diving behaviour during their first day post-release than the fish released from Kåfjord. The Langfjord fish also took longer to navigate out of the fjord than the fish released in Kåfjord, and had more variance in their progression rate.

The high degree of individual variation in dispersal patterns exhibited by the escaped salmon differed from the more direct migratory behaviour of the wild adults (Halttunen et al. 2009, J. G. Davidsen et al. unpubl.). Just over half of the tagged fish went out towards the open ocean, not following the in-migrating wild salmon in the fjord at the same time. The leading hypothesis for the random dispersal of escaped adult farmed salmon is that the migratory performance of cage-reared salmon declines during the post-smolt stage at the end of their first summer in net pens (Skilbrei 2010). Another influence may be the fact that the hatcheries and smolt-rearing areas of the experimental fish were in another fjord system, which may affect their imprinting and migratory instincts. However, one of the tagged fish did return to the Altafjord the following year.

A large escape event may yield dissimilar results. This study mimicked a small 'leak' event; in the case of large escape events, e.g. from a torn pen, escapees may form schools and migrate in a more directed manner. However, the present results are consistent with both small- and large-scale releases in another large Norwegian fjord, which also demonstrated multidirectional migration patterns in escaped salmon (Skilbrei et al. 2010, Skilbrei \& Jørgensen 2010).

The relatively small percentage of fish that entered the river ( $13 \%$ of the tagged fish in the present study) could translate to thousands of potential spawners in a large escape event, possibly outnumbering the wild spawners. For example, from a pen of 100000 salmon, an escape of $13 \%$ would be 13000 farmed fish, which equals the estimated total spawning population of the Alta River (A. H. Rikardsen et al. unpubl. data). However, not all escaped farmed fish found in freshwater will spawn successfully (Carr et al. 1997a,b), and the likelihood that escapees will survive a winter to return to their fjord of origin to spawn is regarded to be small (Thorstad et al. 1998, Whoriskey \& Carr 2001, Jonsson \& Jonsson 2006). That being said, 1 out of the 8 noncaptured fish in the present study returned to the Altafjord the following year, which also represents a return rate of $13 \%$.

The peak period of escapee migration in the Tana River system occurs later than the wild migration (Erkinaro et al. 2010). During mid-August, one of the tagged farmed fish from the present study was recaptured in the Tana River. This exemplifies the possibility that escape events can affect locations at great distances from the escape sites.

Improved recapture strategies may reduce economic losses and ecological risks following an escape event. However, studies pertaining to the prevention of aquaculture escapes should be a priority. Norway has been eliminating farms from the vicinity of important salmon rivers and placing restrictions on infected farms, but this is only just a beginning (Tilseth et al. 1991, Jensen et al. 2010). Jensen et al. (2010), in their review of the causes, consequences and prevention of aquaculture escapes, suggested a 5-component strategy for policymakers. This strategy included (1) mandatory reporting, (2) mechanisms to analyse and learn from the reporting, (3) cause assessments, (4) technical standards for equipment coupled with independent enforcement and (5) mandatory training of fish-farm staff. Skilbrei (2010) suggested that the prevention of escapes during the first marine summer should be a top priority, as the migratory ability of post-smolts was well developed until at least $6 \mathrm{wk}$ following transfer to sea cages in May, whereupon their dispersal rates declined and chances of recapture increased. Other ideas, including the sterilization (Thorstad et al. 2008) and conditioning of farmed fish (Tlusty et al. 2008), may also reduce the risk of negative effects on wild stocks in the future.

\section{CONCLUSIONS}

Recapture efforts after escape events need to be immediate and widespread. During the first day or 2 following the escape event, efforts should target all depths and areas that the fish could travel to given their maximum swimming speed. Following this initial 
period, a more surface- and shoreline-oriented approach may be taken. Coastal bag-net fishers and inriver anglers were highly effective at recapturing escaped farmed salmon. This recapture method would likely produce similar results elsewhere and could be used as a primary mitigative strategy for the future. As bag-net fishing and angling are also generally nonlethal capture methods, they allow for the conservation of wild stocks and can be used during times and in places where gill-netting and other lethal methods are not permitted.

Acknowledgements. This project was funded by the Norwegian Research Council. The authors thank T. Næsje, E. Thorstad, S. Payne, H. Chittenden, E. Hansen, and 4 anonymous reviewers for their comments and advice on earlier versions of this manuscript. Thanks to C. Lien and A. Suhr for their assistance in the field, and Mainstream Norway AS and Grieg Seafood ASA for fish rearing and handling.

\section{LITERATURE CITED}

Baarøy V, Gjerde B, Heggberget TG, Jensen PE and others (2004) Identifisering av rømt oppdrettlaks (Identification of escaped farmed salmon). Utredning fra utvalg nedsatt av Fiskeridirektøren (Report from the Committee to the Director of Fisheries). Fiskeridirektoratet, Bergen (In Norwegian)

Carr JW, Whoriskey FG (2006) The escape of juvenile farmed Atlantic salmon from hatcheries into freshwater streams in New Brunswick, Canada. ICES J Mar Sci 63:1263-1268

Carr JW, Anderson JM, Whoriskey FG, Dilworth T (1997a) The occurrence and spawning of cultured Atlantic salmon (Salmo salar) in a Canadian river. ICES J Mar Sci 54: 1064-1073

Carr JW, Lacroix GL, Anderson JM, Dilworth T (1997b) Movements of non-maturing cultured Atlantic salmon (Salmo salar) in a Canadian river. ICES J Mar Sci 54:1082-1085

Clifford SL, McGinnity P, Ferguson A (1998) Genetic changes in Atlantic salmon (Salmo salar) populations of Northwest Irish rivers resulting from escapes of adult farm salmon. Can J Fish Aquat Sci 55:358-363

> Davidsen JG, Rikardsen AH, Halttunen E, Thorstad EB and others (2009) Migratory behaviour and survival rates of wild northern Atlantic salmon Salmo salar L. post-smolts: effects of environmental factors. J Fish Biol 75:1700-1718

Eilertsen HC, Skarðhamar J (2006) Temperatures of north Norwegian fjords and coastal waters: variability, significance of local processes and air-sea heat exchange. Estuar Coast Shelf Sci 67:530-538

Erkinaro J, Niemelä E, Vähä J, Primmer CR, Brørs S, Hassinen E (2010) Distribution and biological characteristics of escaped farmed salmon in a major subarctic wild salmon river: implications for monitoring. Can J Fish Aquat Sci 67: 130-142

Fiske P, Lund RA, Østborg GM, Fløystad L (2001) Escapes of reared salmon in coastal and marine fisheries in the period 1989-2000. NINA Oppdragsmelding 704:1-26

- Fiske P, Lund RA, Hansen LP (2006) Relationships between the frequency of farmed Atlantic salmon, Salmo salar L., in wild salmon populations and fish farming activity in Norway, 1989-2004. ICES J Mar Sci 63:1182-1189

Fleming IA, Hindar K, Mjølnerød IB, Jonsson B, Balstad T,
Lamberg A (2000) Lifetime success and interactions of farm salmon invading a native population. Proc Biol Sci 267:1517-1523

Ford JS, Myers RA (2008) A global assessment of salmon aquaculture impacts on wild salmonids. PLoS Biol 6:e33

> Gausen D, Moen V (1991) Large-scale escapes of farmed Atlantic salmon (Salmo salar) into Norwegian rivers threaten natural populations. Can J Fish Aquat Sci 48: $426-428$

Halttunen E, Rikardsen AH, Davidsen JG, Thorstad EB, Dempson JB (2009) Survival, migration speed and swimming depth of Atlantic salmon kelts during sea entry and fjord migration. In: Nielsen JL, Fragoso N, Lutcavage M, Arrizabalaga H, Hobday A, Sibert J (eds) Tagging and tracking of marine animals with electronic devices. Reviews: methods and technologies in fish biology and fisheries, Vol 9. Springer-Verlag, Dordrecht, p 35-49

> Hansen LP (2006) Migration and survival of farmed Atlantic salmon (Salmo salar L.) released from two Norwegian fish farms. ICES J Mar Sci 63:1211-1217

Hansen LP, Jacobsen JA, Lund RA (1999) The incidence of escaped farmed Atlantic salmon, Salmo salar L., in the Faroese fishery and estimates of catches of wild salmon. ICES J Mar Sci 56:200-206

> Hindar K, Ryman N, Utter F (1991) Genetic effects of cultured fish on natural fish populations. Can J Fish Aquat Sci 48: 945-957

Hindar K, Fleming IA, McGinnity P, Dieserud O (2006) Genetic and ecological effects of salmon farming on wild salmon: modelling from experimental results. ICES J Mar Sci 63:1234-1247

- Hutchings JA (1991) The threat of extinction to native populations experiencing spawning intrusion by cultured Atlantic salmon. Aquaculture 98:119-132

Jensen Ø, Dempster T, Thorstad EB, Uglem I, Fredheim A (2010) Escapes of fishes from Norwegian sea-cage aquaculture: causes, consequences and prevention. Aquacult Environ Interact 1:71-83

> Jonsson B, Jonsson N (2006) Cultured Atlantic salmon in nature: a review of their ecology and interaction with wild fish. ICES J Mar Sci 63:1162-1181

Lund RA, Økland F, Hansen LP (1991) Farmed Atlantic salmon (Salmo salar) in fisheries and rivers in Norway. Aquaculture 98:143-150

Lura H, Sægrov H (1991) Documentation of successful spawning of escaped farmed female Atlantic salmon, Salmo salar, in Norwegian rivers. Aquaculture 98:151-159

McGinnity P, Stone C, Taggart JB, Cooke D and others (1997) Genetic impact of escaped farmed salmon (Salmo salar L.) on native populations: use of DNA profiling to assess freshwater performance of wild, farmed, and hybrid progeny in a natural river environment. ICES J Mar Sci 54: 998-1008

> McGinnity P, Prodöhl P, Ferguson A, Hynes R and others (2003) Fitness reduction and potential extinction of wild populations of Atlantic salmon, Salmo salar, as a result of interactions with escaped farm salmon. Proc Biol Sci 270: 2443-2450

> Mork J (1991) One-generation effects of farmed fish immigration on the genetic differentiation of wild Atlantic salmon in Norway. Aquaculture 98:267-276

NDF (Norwegian Directorate of Fisheries) (2010) Norwegian aquaculture statistics. NDF, Bergen, available at www. fiskeridir.no/english/statistics/norwegian-aquaculture/ aquaculture-statistics/ (accessed 1 November 2010)

> Olsen RE, Skilbrei OT (2010) Feeding preference of recaptured Atlantic salmon Salmo salar following simulated 
escape from fish pens during autumn. Aquacult Environ Interact 1:167-174

Rikardsen AH, Haugland M, Bjørn PA, Finstad B and others (2004) Geographical differences in early marine feeding of Atlantic salmon post-smolt in Norwegian fjords. J Fish Biol 64:1655-1679

Roberge C, Normandeau É, Einum S, Guderley H, Bernatchez L (2008) Genetic consequences of interbreeding between farmed and wild Atlantic salmon: insights from the transcriptome. Mol Ecol 17:314-324

Statistics Norway (2010) Fishing and farming. Statistics Norway, Oslo, available at www.ssb.no/fiskeri_havbruk_en/ (accessed 1 November 2010)

Skaala Ø, Wennevik V, Glover KA (2006) Evidence of temporal genetic change in wild Atlantic salmon, Salmo salar L., populations affected by farm escapees. ICES J Mar Sci 63: $1224-1233$

Skarðhamar J, Svendsen H (2010) Short-term hydrographic variability in a stratified Arctic fjord. In: Howe JA, Austin WEN, Forwick M, Paetzel M (eds) Fjord systems and archives. Geol Soc Lond Spec Publ 344:35-50

Skilbrei OT (2010) Reduced migratory performance of farmed Atlantic salmon post-smolts from a simulated escape during autumn. Aquacult Environ Interact 1:117-125

Skilbrei OT, Jørgensen T (2010) Recapture of cultured salmon following a large-scale escape experiment. Aquacult Environ Interact 1:107-115

Skilbrei OT, Wennevik V (2006) The use of catch statistics to monitor the abundance of escaped farmed salmon and rainbow trout in the sea. ICES J Mar Sci 63:1190-1200

Skilbrei OT, Holst JC, Asplin L, Holm M (2009) Vertical movements of 'escaped' farmed Atlantic salmon (Salmo salar L.) - a simulation study in a western Norwegian fjord. ICES J Mar Sci 66:278-288

Skilbrei OT, Holst JC, Asplin L, Mortensen S (2010) Horizontal movements of simulated escaped farmed Atlantic salmon (Salmo salar) in a western Norwegian fjord. ICES J Mar Sci 67:1206-1215

Svendsen H (1995) Physical oceanography of coupled fjord-coast systems in northern Norway with special focus

Editorial responsibility: Pablo Sánchez-Jerez,

Alicante, Spain on frontal dynamics and tides. In: Skjoldal HR, Hopkins C, Erikstad KE, Leinaas HP (eds) Ecology of fjords and coastal waters. Elsevier Science BV, Amsterdam, p 49-164

Thorstad EB, Heggberget TG, Økland F (1998) Migratory behaviour of adult wild and escaped farmed Atlantic salmon, Salmo salar L., before, during and after spawning in a Norwegian river. Aquacult Res 29:419-428

Thorstad EB, Fleming IA, McGinnity P, Soto D, Wennevik V, Whoriskey F (2008) Incidence and impacts of escaped farmed Atlantic salmon Salmo salar in nature. NINA Spec Rep 36. Norwegian Institute for Nature and Research (NINA), Trondheim

> Tilseth S, Hansen T, Moller D (1991) Historical development of salmon culture. Aquaculture 98:1-9

Tlusty MF, Andrew J, Baldwin K, Bradley T (2008) Acoustic conditioning for recall/recapture of escaped Atlantic salmon and rainbow trout. Aquaculture 274:57-64

Ugedal O, Næsje TF, Thorstad EB, Forseth T, Saksgård L, Heggberget TG (2008) Twenty years of hydropower regulation in the River Alta: long-term changes in abundance of juvenile and adult Atlantic salmon. Hydrobiologia 609:9-23

Uglem I, Bjørn PA, Mitamura H, Nilsen R (2010) Spatiotemporal distribution of coastal and oceanic Atlantic cod Gadus morhua sub-groups after escape from a farm. Aquacult Environ Interact 1:11-19

Walker RV, Myers KW, Davis ND, Aydin KY and others (2000) Diurnal variation in thermal environment experienced by salmonids in the North Pacific as indicated by data storage tags. Fish Oceanogr 9:171-186

> Whoriskey FG, Carr JW (2001) Returns of transplanted adult, escaped, cultured Atlantic salmon to the Magaguadavic River, New Brunswick. ICES J Mar Sci 58:504-509

Whoriskey FG, Brooking P, Doucette G, Tinker S, Carr JW (2006) Movements and survival of sonically tagged farmed Atlantic salmon released in Cobscook Bay, Maine, USA. ICES J Mar Sci 63:1218-1223

Youngson AF, Dosdat A, Saroglia M, Jordan WC (2001) Genetic interactions between marine finfish species in European aquaculture and wild conspecifics. J Appl Ichthyology 17:153-162

Submitted: July 15, 2010; Accepted: February 24, 2011

Proofs received from author(s): March 22, 2011 